\title{
CORPORATE GOVERNANCE AND FINANCIAL DISTRESS: MALAYSIAN PERSPECTIVE
}

\author{
Noriza Mohd Nasir and Mazurina Mohd Ali*
}

\begin{abstract}
Research aim: The purpose of this study is to examine the relationship between corporate governance mechanisms - board of directors' characteristics (board size, board activity, CEO duality, and board independence) - and financially distressed companies in Malaysia.

Design/ Methodology/ Approach: In order to gather the required data, the secondary data, which are the annual reports of all the selected companies, are obtained from Bursa Malaysia from years 2010 until 2016. Financially distressed companies are defined as those companies that are classified in the Bursa Malaysia Practice Note (PN17). The sample of companies comprises all sectors except banking and financing companies. Levene's Test for Equality of Variances Analysis, Pearson Spearman's Rho Correlations Analysis, and Binary Logistic Regression Analysis are used to analyse the collected data.

Research finding: This study provides evidence that board activity has a significant relationship with financially distressed companies.

Theoretical contribution/ Originality: This study is desired to improve corporate governance mechanisms among financially distressed companies and improve shareholders value.

Practitioner/ Policy implication: This study helps the shareholders, management, potential investors, and other stakeholders of public listed companies to understand how selected board of directors' characteristics are associated with companies in a financial distress situation.

Research limitation/ Implication: The limitation of this research is the timeperiod of the study.

Keywords: Financial Distress, Corporate Governance, Board of Directors, Malaysia

Type of manuscript: Research paper

JEL Classification: M41, M49
\end{abstract}

\section{Introduction}

The growing number of corporate scandals and failure of companies in recent years have attracted more attention to corporate governance than

\footnotetext{
*Corresponding Author: Mazurina Mohd Ali, PhD is a Senior Lecturer at the Faculty of Accountancy, Universiti Teknologi MARA Selangor, Puncak Alam Campus, 42300, Selangor, Malaysia. Email: mazurina@salam.uitm.edu.my

Noriza Mohd Nasir is PhD scholar at the Faculty of Accountancy, UiTM Shah Alam, 40450 Shah Alam, Selangor, Malaysia. Email: Norizamcis@yahoo.com.
} 
ever before (Alabede, 2016). The objective of corporate governance mechanisms is to protect shareholders' interests. Besides that, having good corporate governance can improve the economic development of a country (Sajid, Muhammad, Nasir, \& Farman, 2012). Nevertheless, with the occurrence of an increasing number of cases of corporate scandals and company failures, there is doubt as to whether the current corporate governance mechanisms have been effective in preventing them from happening (Alabede, 2016). Core, Holthausen, \& Larcker (1999) argued that when a company has a weak structure of corporate governance mechanisms, there is the possibility that more agency problems will exist in the company.

In the study by Wruck (1990), a company would fall into a financial distress situation due to economic distress, poor management or a decline in performance. According to the Organization for Economic Cooperation and Development (OECD), when a company is in a financial crisis situation, it reveals that there is a severe deficiency in the company's corporate governance. When a company is in the most needful situation, the existing standards, procedures or practices fail to provide the company with the required checks and balances in order to cultivate sound business practice.

Therefore, in today's business environment, the concept of corporate governance plays a significant and major role in running business activities (Lakshan \& Wijekoon, 2012). After the 1997 financial crisis, most Asian countries dynamically reviewed and strengthened their regulatory frameworks, specifically on corporate governance, transparency, and disclosure (Ho \& Shun Wong, 2001). This indicates that businesses are already aware of the importance of corporate governance in business development.

According to the agency theory, one of the important elements or components of corporate governance is the board of directors (Tao \& Hutchinson, 2013). The board of directors is considered to be the main component in corporate governance as they play a vital role in monitoring the performance of companies (Fama \& Jensen, 1983; Walsh \& Seward, 1990; Shukeri, Shin, \& Shaari, 2012;). This is founded on the basis that the characteristics of the board members determine the board's capability to control and supervise managers, supply information and give guidance to managers, monitor compliance with applicable laws and regulations, and form a linkage between the company and the external environment (Carter, D'Souza, Simkins, \& Simpson, 2010). The board of directors is also responsible for making sure that the top managers are behaving in a manner that will provide the most 
favourable value for shareholders (Coles, McWilliams, \& Sen, 2001). Consequently, there are many studies that focus on board's characteristics, such as its composition and size (Tao \& Hutchinson, 2013).

However, in recent years, there has been criticism of corporate governance, especially concerning the reforms of the board of directors. The issue that has been highlighted is that the directors on the board do not perform their role effectively (Abdullah, 2006). Therefore, the aim of this study is to examine the relationship between corporate governance mechanisms - which is proxied by the board of directors' characteristics, namely, board size, board activity, CEO duality, and board independence - and financially distressed companies in Malaysia. This study will contribute to shareholders, management, potential investors, and other stakeholders of public listed companies to understand how selected board of directors' characteristics are associated with companies in financial distress.

The remaining sections of this study are structured as follows. The literature review and hypotheses development are in Section 2. Methodology is described in Section 3. The empirical model, tests, and findings are presented and discussed in Section 4. The final section, Section 5, provides the concluding remarks.

\section{Literature Review and Hypotheses Development}

The association between corporate governance and financial distress is a popular issue and has been a topic for academic debate since the 1980s (Shahwan, 2015). The existence of a relationship between corporate governance and financial distress is not because financial distress is a discrete event, but, to a certain extent, it is a late stage of a "protracted process of decline" and a "downward spiral" (Hambrick \& D'Aveni, 1992). The important features of the downward spiral include early weaknesses in business performance, extreme strategic actions, and abrupt environmental decline. Hambrick \& D'Aveni (1992) suggested that deterioration of the top management team is a central element of the downward spiral of large corporate failures. It could be argued that the risk of financial distress could be avoided if the board of directors is effective, and, hence, companies do not have the need to borrow excessively (Abdullah, 2006).

A few previous studies have empirically examined the relationship or association between various corporate governance elements and financially distressed companies. Exceptions are Manzaneque et al. (2016) for Spanish companies; Miglani, Ahmed, \& Henry (2015) for 
Australian companies; Hong-xia, Zong-jun, \& Xiao-lan (2008) for Chinese companies; Abdullah (2006) for Malaysian companies; and Elloumi \& Gueyié (2001) for Canadian companies.

Manzaneque et al. (2016) conducted an empirical study using a matched-pairs research design with 308 observations for the period from 2007 to 2012 with half classified as distressed and half non-distressed. The study found that corporate governance mechanisms - board ownership, board size, and proportion of independent directors decrease the probability of financial distress. However, institutional or non-institutional large shareholders, ownership concentration, and CEO duality have no significant impact on the likelihood of financial distress.

Miglani et al. (2015) examined the role of voluntary adoption of corporate governance mechanisms in justifying the financial distress status of companies. The study was carried out using a sample of 171 financially distressed and 106 non-financially distressed Australian companies for a period of 5 years. The study was conducted prior to the introduction of the ASX Corporate Governance Council Code in 2003. The study found that, in particular, both greater levels of director and block holder ownership, and the presence of board audit committee decrease the likelihood of financial distress. Nevertheless, CEO duality and higher board independence do not lead to lower levels of financial distress. The study also suggested that financial distress can be reduced by the voluntary adoption of certain corporate governance structures.

Hong-xia et al. (2008) examined the influence of ownership structure, managerial agency costs, independent directors, and audit opinion on financially distressed companies using a sample of 404 financially distressed companies listed on Chinese stock markets and a sample of 404 matched non-financially distressed companies. The period of study covered from 1998 until 2005. The study showed that ownership concentration, auditors' opinion, independent directors, state ownership and ultimate owner are negatively related with the likelihood of financial distress. Meanwhile, the administrative expense ratio is positively associated with the probability of financial distress.

Abdullah (2006) conducted a study on Malaysian companies with data taken from 1999-2001, and after the issuance of Malaysian of Corporate Governance in 2001. This study was conducted in the period in which Malaysia had just implemented corporate governance. The result indicated that board independence and CEO duality are not associated with the financial distressed status. Management and nonexecutive directors' interests and outside block holders are negatively associated with financial distress. The evidence also supports the 
argument that ownership by outside block holders and non-executive directors increase their incentive to monitor management.

Elloumi \& Gueyié (2001) examined various corporate governance attributes, such as equity ownership of outside directors, independence of board CEO duality, with the likelihood of financial distress of Canadian companies. The sample data used in the study consisted of 46 financial distress companies and 46 healthy companies from 1994 to 1998. They found that independence of board and ownership of outside directors are negatively associated with the likelihood of financial distress. However, the presence of CEO duality does not show any significant association with financially distressed companies.

For the purpose of this study, we have extended the literature by examining other governance components that are specific to the board of directors' attributes. The selected board of directors' attributes are the board size, board independence, board activity, and CEO duality. These attributes are selected because board of directors is one of the main and most important elements in the corporate governance structure. To the authors' knowledge, this study is the first to provide related evidence concerning corporate governance and financial distress after the issuance of the revised Malaysian Corporate Governance Code 2007 (MCCG 2007) and the 2007 - 2009 financial crisis. Thus, with the aim of contributing to the literature of corporate governance studies, our findings may contribute in identifying the board of director's attributes that are associated with financially distressed companies.

\subsection{Hypotheses Development}

\subsubsection{Board Size}

Board size is defined as the number of executive and non-executive directors on the board (O'Connell \& Cramer, 2010). It is important to have the right number of members on the board because the size of the board can determine the quality of managerial monitoring and control (Lakshan \& Wijekoon, 2012). Although by having a larger board size better advice can be given, at the same time, coordination problems may occur (Jensen, 1993). Furthermore, in the process of coping with unexpected changes in the business environment and companies' feasibility, especially during a financial crisis, timely and proper decisions are vital (Chen, 2014b).

In respect of the issue of financial distress, the study by Fich \& Slezak (2008) stated that when a company is in financial distress, smaller and more independent boards are more effective at avoiding bankruptcy status. This is supported by Jensen (1993), who found that a smaller 
board can perform better as it works more effectively. However, the study by Brédart (2014) found that companies with more directors on the board have less probability of experiencing financial distress and filing for bankruptcy. This finding is supported by Lamberto \& Rath (2010), who contended that companies with a larger size board would be less likely to fail because of the accountability of the directors. In this regard, since there are mixed findings concerning the relationship, the hypothesis regarding the size of the board is asserted as follows:

H1: $\quad$ There is a significant relationship between board size and financially distressed company

\subsubsection{Board Independence}

According to Editorial (2003), independent non-executive directors are considered as the "mainstay of good governance". Alhaji, Baba, \& Yusoff (2013) stated that non-executive directors are also described as the guarantors concerning the integrity and accountability of companies' boards. The Malaysian Code on Corporate Governance 2007 recommended that to have a balanced board, independent non-executive directors should make up at least one-third of the board (Securities Commission Malaysia, 2007). Having independent non-executive directors on the board can help maintain the effectiveness of the board in making more objective decisions. The agency theory argues that more independent directors on the board will help lead to better company performance as it assumes that, by nature, managers are opportunistic and individualistic. Thus, effective and competent independent directors on the board are vital to protect the interests of the shareholders (Witteloostuijn, 2009). This is in line with Fama \& Jensen (1983) who found that boards comprising more independent directors are more effective in monitoring and enhancing shareholders' wealth. Jensen \& Meckling (1976) argued that the composition of independent directors on the board is in line with the agency theory, which states that because of the separation between ownership and control, managers would have a tendency to pursue their own target at the expense of the shareholders. Therefore, independent directors on the board can assist in monitoring and controlling management. Furthermore, in the situation where there is disagreement between the directors and managers, independent board members act as an intermediary. In addition, independent directors contribute to preventing management taking advantage for their own benefit, such as increasing their compensation. 
In respect of the relationship between board independence and financially distressed companies, in a study on distressed Canadian companies by Elloumi \& Gueyié (2001), financially distressed companies have a significantly lower percentage of independent directors. Miglani, Ahmed, \& Henry (2015) found that greater board independence decreases the likelihood of financial distress. Another study, by Hong-xia et al. (2008), also found that more independent directors on the board might lead to a lower probability of financial distress. Hence, the hypothesis concerning the proportion of independent directors is as follows:

H2: $\quad$ There is a negative significant relationship between board independence and financially distressed company

\subsubsection{Board Activity}

According to the Business Dictionary, board activity or board meeting frequency refers to the formal meetings of the board of directors of a company that are held at definite intervals to discuss issues and problems that arise in the company. Board activity is a vital element of board operations (Vafeas, 1999; Adams, 2003; and Brick \& Chidambaran, 2008). Jensen (1993) doubted the effectiveness of board meetings as, generally, the CEO always determines the agenda and the information that should be given to the board members at the board meeting. This limitation on information may hinder talented board members from contributing effectively in monitoring and evaluating CEO performance and the strategy of the company. Jensen (1993) also suggested that board activity is more reactive than proactive as the board meets more often following poor performance. This is supported by Vafeas (1999), who found that when the performance of a company is poor, the board increases the level of board activity. The same article suggests that boards that meet more often are valued less by the market. In the context of this study, more meetings will be held when a company is in financial distress. Hence, we assert our hypothesis as follows:

H3: $\quad$ There is a positive significant relationship between board activity and financially distressed company

According to Chen (2014a), CEO duality refers to the situation where the position of the chief executive officer (CEO) and the chairman of the board are served by the same individual. However, there are some weaknesses if the position of the CEO and the chairman of the board are 
hold by the same person or individual. The CEO can be very powerful as there will be no individual to monitor his or her actions or decisions. Moreover, the board may face difficulties when it cannot perform its tasks effectively including evaluating and firing incompetent directors due to the failure of the internal control system (Fama \& Jensen, 1983). Furthermore, when the CEO also holds the position of chairman, he or she can maximize their own interests at the expense of the shareholders (Yusoff \& Alhaji, 2012) and (Coşkun \& Sayilir, 2012). In contrast, the agency theory argues that a separate leadership structure is necessary for a clear separation of the responsibilities of the CEO and the chairman of the board. The fundamental argument of the agency theory is that separation of the roles of the CEO and the chairman is necessary to protect the interests of the shareholders (Chen, 2014a). Moreover, if the roles of the chairman and CEO are given to two separate individuals, the CEO's overall power will reduce and the ability of the board to execute its appropriate supervisory role will increase (Fama \& Jensen, 1983). Therefore, a separate leadership structure is suggested to monitor the performance of the CEO and chairman objectively and effectively.

In respect of the relationship with financial distress, Simpson \& Gleason (1999) argued that when an individual holds the position as both CEO and chairman of the board, the probability of financial distress is lower. This is because the combination of CEO and chairman in one position may influence the internal control system of a banking company, which will reduce the probability of financial distress in the company. The study of Miglani et al. (2015) also found that CEO duality reduces the probability of financial distress. Nevertheless, the study by Hambrick \& D'Aveni, (1992) found that companies in which the CEO acts as the board chairman are more likely to go bankrupt compared to companies that separate the role of the CEO and the chairman. Although the research evidence is mixed, it is predicted that CEO duality has a positive relationship with that of a financially distressed company.

H2: $\quad$ There is a positive relationship between CEO duality and financially
distressed company

\section{Methodology}

In this study, secondary data are used to answer the research questions and to test the hypotheses of this study. In the study by Lima and Sanvicente (2013), the use of secondary data can eliminate the risk of third-party responses. In order to test the proposed hypotheses, data are 
collected from Bursa Malaysia. Financially distressed companies are defined as those companies that are classified in the Bursa Malaysia Practice Note (PN17) sector; previously known as Practice Note (PN4). In 2001, Bursa Malaysia issued PN4 after the 1997 crisis. However, in 2005 Bursa Malaysia issued PN17 to replace PN4, which refers to financially distressed companies.

The criteria listed in PN17 are used by Bursa Malaysia to identify companies that are necessary to regularize their financial situation (Abdullah, 2006). If companies fall within the definition of PN17 and in order to maintain their listing status, they are required to submit proposals to the approving authority to restructure and revive the companies. However, if the companies are not able or fail to restructure and revive their financial conditions within the given time frame, they will be de-listed from Bursa Malaysia. Six criteria have been outlined by Bursa Malaysia on PN17, which are as follows (Bursa Malaysia, 2015): (i) there is a deficit in the shareholders' equity; (ii) there is an appointment of receivers and/or managers over the property of the listed company; (iii) there is a winding up of a listed company's subsidiary or associated company; (iv) there is an adverse opinion or disclaimer in the listed company's latest audited financial statements; (v) there is an emphasis on matter of opinion on the listed company's ability to continue as a going concern; or (vi) there is a default in payment by a listed company, its major subsidiary or major associated company.

When a company is unable to meet its current commitments or obligations, a company is said to be in a financially distressed situation. Therefore, according to the definition, PN17 companies are in a financially distressed condition. The data of 57 financially distressed companies are taken from Bursa Malaysia for the period 2010-2016 for PN17 companies. The period from 2010-2016 is studied because many companies had economic and financial problems during this period and also the period is after the recent financial crisis. This is proven by more companies being listed as PN17 during this time period. From the original data of 57 financially distressed companies, three (3) companies are excluded because the companies are from the financial and insurance sectors. Four (4) companies are also excluded from the sample because of the change in their financial year. Thus, the final sample comprised 50 financially distressed companies (refer to Figure 1). Figure 1 shows the statistics for the financially distressed companies when they first listed under PN17. As shown in Figure 1, 19 companies listed under PN17 in year 2010. From 2011 to 2013, it shows an increasing trend in which 2 companies, 10 companies, and 12 companies listed under PN17 in years 
2011, 2012, and 2013, respectively. The statistics then show a decreasing trend whereby in years 2014 and 2015, companies listed under PN17 are 6 and 1, respectively. In year 2016, no companies are listed under PN17.

According to the prior literature, each of these financially distressed companies is matched with non-financially distressed companies based on these two bases, which are Bursa Malaysia sectorial classification and companies have similar total assets (Brédart, 2014). The total of financially distressed companies and non-financially distressed companies is 100 companies. When performing the analysis, out of 50 financially distressed companies, 3 companies are removed because of outlier data. The matched non-financially distressed companies are also removed from the sample, which leads to a final total of 94 companies.

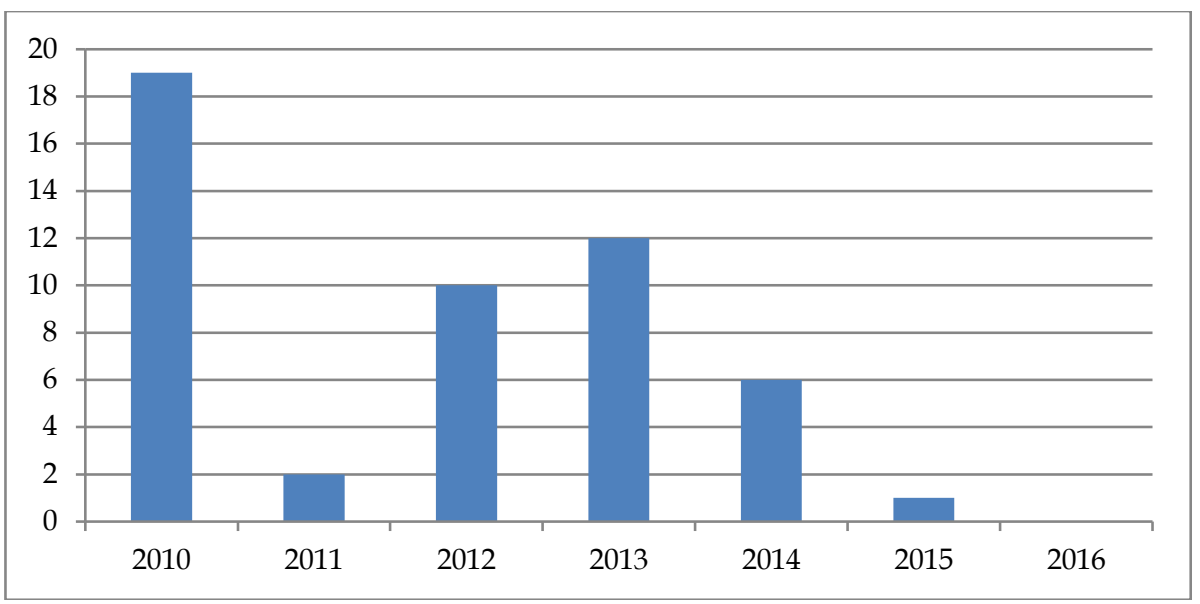

Figure 1. Statistics of PN17 companies

Descriptive statistics are conducted to provide simple summaries on the financially distressed and non-financially distressed companies. Frequency and percentage distribution from descriptive statistics are used to analyse the characteristics. Besides that, the Levene's Test for Equality of Variances is used to test the difference of board size, board independence, board activity, and CEO duality in financially distressed companies and non-financially distressed companies. Spearman's Rho Correlations analysis is also performed for analysing the multicollinearity between the variables used. Two or more perfectly multicollinear variables in the regression will influence the results of the estimation. Lastly, since the dependent variable, financially distressed, is dichotomous, Binary Logistic Regression analysis is used to analyse the strength of the relationship between the independent variables and the 
dependent variable (Brédart, 2014). The equation for Binary Logistic Regression analysis is as follows:

$$
\begin{aligned}
\text { FIN_DISTRESS }= & \alpha+\beta_{1} S I Z E \_B O D+\beta_{2} I N D \_B O D+\beta_{3} A C T \_B O D \\
& +\beta_{4} D U A L I T Y+\varepsilon
\end{aligned}
$$

where

FIN_DISTRESS is an indicator variable that takes a value of 1 if financially distressed company, 0 if non-financially distressed company.

SIZE_BOD represents the number of directors on the board.

$I N D \_B O D$ represents the proportion of independent directors on the board.

$A C T \_B O D$ represent the number of board meetings held.

DUALITY is an indicator variable that takes a value of 1 if chairman and chief executive officer are the same person, 0 if chairman and chief executive officer are not the same person.

\section{Results and Discussions}

\subsection{Descriptive Analysis}

Table 1 shows the descriptive analysis of the 47 financially distressed companies and their comparison companies that make up a total of 94 companies from the year 2010 to year 2016.

\begin{tabular}{|c|c|c|c|c|c|c|}
\hline & $\mathrm{N}$ & Minimum & Max & $\begin{array}{c}\text { Std. } \\
\text { Deviation }\end{array}$ & Skewness & Kurtosis \\
\hline FIN_DISTRESS & 94 & 0 & 1 & 0.503 & 0.000 & -2.044 \\
\hline SIZE_BOD & 94 & 3 & 11 & 1.743 & 0.578 & -0.067 \\
\hline IND_BOD & 94 & $25 \%$ & $75 \%$ & 0.133 & 0.176 & 0.163 \\
\hline ACT_BOD & 94 & 4 & 11 & 1.485 & 1.405 & 2.076 \\
\hline DUALITY & 94 & 0 & 1 & 0.438 & 1.141 & -0.715 \\
\hline $\begin{array}{l}\text { Industry } \\
\text { Frequency }\end{array}$ & Industrials & $\begin{array}{l}\text { Trading \& } \\
\text { Services }\end{array}$ & $\begin{array}{l}\text { Consumer } \\
\text { Products }\end{array}$ & $\begin{array}{l}\text { Industrial } \\
\text { Products }\end{array}$ & Tech & Property \\
\hline $\mathrm{N}=47$ & 15 & 10 & 13 & 6 & 2 & 1 \\
\hline
\end{tabular}

Table 1. Descriptive Statistics

Notes: $\quad$ Table 1 shows the descriptive statistics for 1) financially distressed companies (FIN_DISTRESS), being 1 = financially distressed company and $0=$ nonfinancially distressed company, 2) size of board of directors (SIZE_BOD), 3) number of independent directors on the board of directors (IND_BOD), 4) number of meetings held (ACT_BOD), 5) CEO duality, being $0=$ chairman and $\mathrm{CEO}$ are not the same person and $1=$ chairman and $\mathrm{CEO}$ are the same person. 
From Table 1, we can observe that for variable SIZE_BOD, the largest board of directors consists of 11 directors, while the smallest board of directors consists of only 3 directors. In term of frequency of board meetings (ACT_BOD), the highest number of meetings conducted in a year is 11 meetings whereas the lowest number of meetings convened is 4 meetings per year. For IND_BOD, the minimum ratio of independent directors on a board of directors is only $25 \%$, meaning out of eight directors, only two are independent directors. The maximum ratio of independent directors is $75 \%$. This indicates that out of eight directors on a board of directors, there are six independent directors. The breakdown of data on financially distressed companies according to the Bursa Malaysia sectorial classification can also be seen in Table 1, where the Industrial sector suffers the highest number of companies being classified as financially distressed companies with 15 companies. This is followed by the Consumer Products sector, which has 13 financially distressed companies. The third highest sector is the Trading and Services sector with 10 companies classified as financially distressed. It continues with the Industrial Products sector with 6 financially distressed companies, the Technology sector with 2 financially distressed companies, and, lastly, the Property sector, with 1 financially distressed company.

Table 2. Descriptive analysis and Levene's test

\begin{tabular}{lcccccc}
\hline & \multicolumn{2}{c}{$\begin{array}{c}\text { Financially } \\
\text { Distressed }\end{array}$} & \multicolumn{2}{c}{$\begin{array}{c}\text { Non-Financially } \\
\text { Distressed }\end{array}$} & \multicolumn{2}{c}{$\begin{array}{c}\text { Levene's Test for } \\
\text { Equality of Variances }\end{array}$} \\
\cline { 2 - 8 } & Mean & Count & Mean & Count & F & Sig. (2-tailed) \\
\hline SIZE_BOD & 6.30 & & 6.91 & & 0.199 & $0.086^{* *}$ \\
IND_BOD & 0.49 & & 0.45 & & 1.731 & 0.311 \\
ACT_BOD & 5.87 & & 5.00 & & 6.992 & $0.004^{*}$ \\
\multirow{2}{*}{ DUALITY Non-Duality } & & 32 & & 39 & 11.842 & $0.095^{* *}$ \\
& & 15 & & 8 & & \\
\end{tabular}

Notes: Table 2 shows 1) size of board of directors (SIZE_BOD), 2) number of independent directors on board of directors (IND_BOD), 3) number of meetings held

(ACT_BOD), 4) CEO duality, being $0=$ chairman and CEO are not the same person and $1=$ chairman and CEO are the same person.

*significant at $1 \%$; ${ }^{* *}$ significant at $10 \%$

In terms of DUALITY, in Table 2, the number of financially distressed companies that practice CEO duality is 15 companies and the remaining 32 companies do not practice CEO duality. In comparison, the number of non-financially distressed companies that practice CEO duality is less than that for the financially distressed companies, with only 8 companies. The remaining 39 non-financially distressed companies do not practice CEO duality. In general, financially distressed 
companies practice more CEO duality compared to non-financially distressed companies (Brédart, 2014).

\subsection{Levene's Test Analysis}

Table 2 shows the comparison between financially distressed and nonfinancially distressed companies. Financially distressed companies have smaller boards of directors $($ mean $=6.30)$ compared to the non-financially distressed companies (mean 6.91). Financially distressed companies also have more independent directors (mean $=49 \%$ ) and conduct board meetings more frequently (mean $=6$ ) compared to non-financially distressed companies ( mean $=45 \%$ and mean $=5$ respectively). In terms of practicing CEO duality, Table 2 shows that financially distressed companies have higher CEO duality (count $=15$ ) compared to nonfinancially distressed companies (count $=8$ ). Overall, the results in Table 2 on the descriptive analysis support all the selection criteria used in selecting the matched companies; this is supported by other studies (Brédart, 2014; and Abdullah, 2006).

In respect of Levene's Test for Equality of Variances, it can be seen that board size SIZE_BOD and CEO duality are different between financially distressed companies and non-financially distressed companies. They are significant at $10 \%$. Furthermore, board activity ACT_BOD of financially distressed companies is also significantly different than the board activity of non-financially distressed companies. The significant level is at $1 \%$. However, the independent directors of financially distressed IND_BOD companies are not significantly different than that of non-financially distressed companies. Even though the difference is insignificant, the financially distressed companies have a higher proportion of independent directors on the board of directors compared to non-financially distressed companies.

\subsection{Correlation Analysis}

Correlation analysis is performed for analysing the multicollinearity between the variables used. Two or more perfectly multicollinear variables in the regression will influence the results of the estimation. If the variables have a correlation coefficient value close to 1 or -1 , the variables are considered to be highly correlated. From Table 3, it can be observed that the variables suffered no multicollinearity problem. From Table 3, we can see that FIN_DISTRESS is positively correlated with SIZE_BOD. 
Table 3. Spearman's Rho Correlations Matrix Financially Distressed Companies

\begin{tabular}{|c|c|c|c|c|c|c|}
\hline & & $\begin{array}{c}\text { FIN_ } \\
\text { DISTR } \\
\text { ESS } \\
\end{array}$ & $\begin{array}{c}S I Z E_{-} \\
B O D\end{array}$ & $\begin{array}{c}\text { IND_B } \\
O D\end{array}$ & $\begin{array}{c}A C T \_B \\
O D\end{array}$ & $\begin{array}{c}\text { DUALI } \\
\text { TY }\end{array}$ \\
\hline \multirow{2}{*}{ FIN_DISTRESS } & Coef. & 1.000 & -0.189 & 0.098 & $0.302^{* *}$ & 0.173 \\
\hline & $p$-value & - & 0.068 & 0.349 & 0.003 & 0.095 \\
\hline \multirow{2}{*}{$S I Z E \_B O D$} & Coef. & -0.189 & 1.000 & $-0.330^{* *}$ & -0.054 & $-0.237^{*}$ \\
\hline & $p$-value & 0.068 & . & 0.001 & 0.606 & 0.022 \\
\hline \multirow{2}{*}{ IND_BOD } & Coef. & 0.098 & $-0.330^{* *}$ & 1.000 & 0.048 & 0.016 \\
\hline & $p$-value & 0.349 & 0.001 & & 0.643 & 0.878 \\
\hline \multirow{2}{*}{$A C T \_B O D$} & Coef. & $0.302^{* *}$ & -0.054 & 0.048 & 1.000 & 0.065 \\
\hline & $p$-value & 0.003 & 0.606 & 0.643 & . & 0.536 \\
\hline \multirow{2}{*}{ DUALITY } & Coef. & 0.173 & $-0.237^{*}$ & 0.016 & 0.065 & 1.000 \\
\hline & $p$-value & 0.095 & 0.022 & 0.878 & 0.536 & . \\
\hline
\end{tabular}

Notes: Table 3 shows the correlation analysis for 1) financially distressed companies (FIN_DISTRESS), being 1 = financially distressed company and $0=$ non-financially distressed company, 2) size of board of directors (SIZE_BOD), 3) number of independent directors on board of directors (IND_BOD), 4) number of meetings held (ACT_BOD), 5) CEO duality, being $0=$ chairman and CEO are not the same person and $1=$ chairman and CEO are the same person.

** Correlation is significant at the 0.01 level (2-tailed); * Correlation is significant at the 0.05 level (2-tailed).

However, the correlation is not significant. FIN_DISTRESS is negatively correlated with IND_BOD, ACT_BOD, and DUALITY. Of the three independent variables, FIN_DISTRESS is only significantly correlated with ACT_BOD. It is significant at 1\%. As such, we can look forward to a negative relationship between FIN_DISTRESS and ACT_BOD in the regression analysis later on.

\subsection{Binary Logistic Regression Analysis}

Table 4 shows the binary logistic regression result of the research model; as follows:

$$
\begin{aligned}
\text { FIN_DISTRESS }= & \alpha+\beta_{1} S I Z E \_B O D+\beta_{2} I N D \_B O D+\beta_{3} A C T \_B O D \\
& +\beta_{4} D U A L I T Y+\varepsilon
\end{aligned}
$$

Binary logistic regression analysis is adopted due to the categorical nature of the dependent variable FIN_DISTRESS. Based on the result, it can be seen that $R$ square for the regression model above is $17.1 \%$. This means that the independent variables explain $17 \%$ of the prediction of the dependent variables. In addition, the Hosmer and Lemeshow test suggests the model is a good fit to the data, as indicated by the significant value of more than $0.05(\mathrm{p}=0.900)$. 
With regard of the regression result, we can see that FIN_DISTRESS has a negative relationship with SIZE_BOD, suggesting that if the company has bigger board of directors, the probability of being financially distressed is lower. This is consistent with the hypothesis (H1) that predicts that a bigger board of directors will reduce the likelihood of financial distress. By having more directors on the board, it may enable the management team to make better informed decisions. In the study by Lamberto \& Rath (2010), it is expected that a company with a larger size would be less likely to fail because of the accountability of the directors. By having greater control and monitoring, the agency cost can be reduced which may discourage any misallocation of funds (Lamberto \& Rath, 2010). Moreover, bigger board size may increase the monitoring and controlling of the CEO (Brédart, 2014). However, the result for H1 shown in the table is insignificant $(p=0.300)$. For the IND_BOD variable, the result shows a positive relationship with FIN_DISTRESS. This suggests that a larger number of independent directors on the board will lead to the company being more likely to suffer financial distress. This is inconsistent with the second hypothesis (H2) that predicts that a board of directors that has more independent directors can help the company to avoid being financially distressed. However, the result for $\mathrm{H} 2$ is insignificant $(p=0.651)$.

Table 4. Binary Logistic Regression

\begin{tabular}{lcccc}
\hline & B & Wald & Sig. & Exp(B) \\
\hline SIZE_BOD & -0.148 & 1.076 & 0.300 & 0.863 \\
IND_BOD & 0.862 & 0.205 & 0.651 & 2.369 \\
ACT_BOD & 0.466 & 6.364 & $0.012^{* *}$ & 1.593 \\
DUALITY & 0.629 & 1.324 & 0.250 & 1.876 \\
Constant & -1.435 & 0.664 & 0.415 & 0.238 \\
Nagelkerke R Square & & & 0.17 \\
Hosmer and Lemeshow Test (Chi-square) & & & 4.183 (sig. 0.840$)$ \\
Classification performance (No of observation) & & & $66 \%(94)$ \\
\hline
\end{tabular}

Notes: Table 4 shows the logistic regression analysis for 1) financially distressed companies (FIN_DISTRESS), being 1 = financially distressed and $0=$ non-financially distressed company, 2) size of board of directors (SIZE_BOD), 3) number of independent directors on the board of directors (IND_BOD), 4) number of meetings held (ACT_BOD), 5) CEO duality, being $0=$ chairman and CEO are not the same person and $1=$ chairman and $\mathrm{CEO}$ are the same person.

**significant at $5 \%$

For the third variable, which is ACT_BOD, the result shows that more board of directors' meetings are arranged for financially distressed companies, which can be seen from the positive relationship between the dependent variable FIN_DISTRESS and the independent variable 
ACT_BOD. This is because for companies on the verge of collapse, the board needs to convene more meetings to address various issues. This indicates that in responding to tough years of operation, one of the strategies taken by the board is to have frequent board meetings (Vafeas, 1999). This result agrees with the third hypothesis (H3) and the regression result is significant at the $5 \%$ level $(p=0.012)$.

Table 4 also shows the regression result of FIN_DISTRESS with DUALITY. The fourth hypothesis (H4) predicts that the regression would have a positive relationship, which suggests that if the company practices CEO duality, then the probability of the company having financial distress is higher. The result shows a positive relationship, which indicates that companies that practice CEO duality are more likely to experience financial distress. The same individual holding the CEO and chairman position may increase the agency costs and the risk of entrenchment (Fama \& Jensen, 1983 and Jensen, 1993). When the chairman and CEO are the same person, the probability of misuse of power is higher. As stated by Hambrick \& D'Aveni (1992), a powerful $\mathrm{CEO} /$ chairman may use his or her influence or power not to effect change. However, the result for $\mathrm{H} 4$ is insignificant $(\mathrm{p}=0.250)$. Below is the summary of the regression results.

Table 5. Summary of regression results

\begin{tabular}{cccc}
\hline & Predicted Result & Regressed Result & $p$-value \\
\hline SIZE_BOD & Significant & Negative & Insignificant \\
IND_BOD & Negative & Positive & Insignificant \\
ACT_BOD & Positive & Positive & Significant \\
DUALITY & Positive & Positive & Insignificant \\
\hline
\end{tabular}

Notes: Table 5 shows the logistic regression analysis for 1 ) financially distressed companies (FIN_DISTRESS), being 1 = financially distressed company and $0=$ nonfinancially distressed company, 2) size of board of directors (SIZE_BOD), 3) number of independent directors on the board of directors (IND_BOD), 4) number of meetings held (ACT_BOD), 5) CEO duality, being $0=$ chairman and CEO are not the same person and $1=$ chairman and CEO are the same person.

In a nutshell, from Table 5 on the summary of regression result, the predicted results for all the independent variables are similar with the regressed result except for the IND_BOD. In detail, the predicted result and the regressed result for SIZE_BOD are negative but not significant. The predicted result for IND_BOD is negative, but the regressed result is positive, however, it is not significant. The predicted result for ACT_BOD is positive, and the regressed result is positive; and it is significant. Lastly, the predicted result for DUALITY is positive and the regressed result is also positive, but it is not significant. Overall, in terms 
of significant relationships, only board activity (ACT_BOD) has a significant relationship with financially distressed companies.

\section{Conclusion}

This study contributes to the corporate governance literature by examining the relationship between the board of directors' attributes and the financial distress status of Malaysian listed companies. The period covered in this study is from the year 2010 until 2016. In respect of the differences between financially distressed companies and non-financially distressed companies, using Levene's Test for Equality of Variances, there are significant differences at $10 \%$ for board size and CEO duality of financially distressed companies and non-financially distressed companies. This gives an indication that the board size of healthy companies is bigger compared that of financially distressed companies. Moreover, for board activity, it is more significant at $1 \%$ for the board activity of financially distressed companies and non-financially distressed companies. This reveals that more meetings are held by companies in a financially distressed situation compared to nonfinancially distressed companies.

In terms of the relationship between board of director's attributes and financially distressed companies, the results from the binary logistic regression analysis show that there is a significant positive relationship between board activity and financially distressed companies. The results give evidence that more board of directors' meetings are held when the companies are financially distressed. However, board size, board independence, and CEO duality have no significant relationship with financially distressed companies. The findings on board activity a consistent with Vafeas (1999), who indicates that during poor performance, boards will respond by having more board activity with the objective being to improve the performance of the company. It is suggested that more frequent board activity during financial distress can be a good strategy for those directors with limited interaction time to sit together and discuss the best strategies to end the company's financial distress. This also provides evidence that board activity tends to be more reactive rather than proactive (Jensen, 1993).

In summary, this study provides some important contributions for the empirical literature about the influence of corporate governance mechanisms on financial distress. First, the study provides empirical evidence concerning the relationship between boards of directors' attributes and financially distressed companies in the Malaysian context where corporate governance has been implemented since 2000. This 
means with respect to the data taken from 2010 until 2016, the study is ten (10) years after the implementation of the corporate governance framework in Malaysia. Second, this study provides empirical evidence concerning the significant relationship between board activity and financially distressed companies. This evidence shows that more board meetings are conducted during financial distress indicating the way that boards respond during company crises. Hence, the implications for management are that when the company is having more frequent board meetings it will give some indication that the company is having financial difficulties, which will lead to the financial distress. From the academic perspective, this study adds to the knowledge concerning the association of selected board of directors' characteristics with companies in financial distress.

However, there is a limitation on this study concerning the period for which the data were taken. The data are selected from Practice Note 17 (PN17) of Bursa Malaysia for seven (7) years (2010-2016). The result of the study might be different if the data are taken for a longer period. Finally, with regards to recommendations, it is recommended that, in future, a similar study should be conducted but to extend the years of data taken. For example, instead of seven (7) years, the data should be chosen for ten (10) or fifteen (15) years. Furthermore, it is suggested to extend the study on another variable, which is risk management. Risk management is another important element in corporate governance, especially as risk management has been recommended in the Malaysian Code on Corporate Governance 2012 (MCCG 2012).

\section{References}

Abdullah, S. N. (2006). Board structure and ownership in Malaysia: The case of distressed listed companies. Corporate Governance, 6(5), 582594.

Alabede, J. O. (2016). Effect of board diversity on corporate governance structure and operating performance: Evidence from the UK listed firms. Asian Journal of Accounting and Governance, 80, 67-80.

Alhaji, I. A., Baba, M. I., \& Yusoff, W. F. W. (2013). The relationship between independent non executive directors' and audit committee on firm performance among Malaysian listed companies. Proceeding Book of ICEFMO, 2013, Malaysia, 107-113.

Brédart, X. (2014). Financial distress and corporate governance: The impact of board configuration. International Business Research, 7(3), 72-81. 
Brick, I. E., \& Chidambaran, N. K. (2008). Board monitoring, firm risk, and external regulation. Journal of Regulatory Economics, 33(1), 87-116. Bursa Malaysia. (2015). Practice Note 2017. Retrieved from http://customer.bursamalaysia.com

Carter, D. A., D'Souza, F., Simkins, B. J., \& Simpson, W. G. (2010). The gender and ethnic diversity of US boards and board committees and firm financial performance. Corporate Governance, 18(5), 396-414.

Chen, H. (2014a). CEO duality and firm performance: An empirical study of EU listed firms. 3rdIBA Bachelor Thesis Conference, 1-10.

Chen, I. (2014b). Financial crisis and the dynamics of corporate governance: Evidence from Taiwan's listed firms. International Review of Economics and Finance, 32, 3-28.

Coles, J. W., McWilliams, V. B., \& Sen, N. (2001). An examination of the relationship of governance machanisms to performance. Journal of Management, 27(1), 23-50.

Core, J. E., Holthausen, R. W., \& Larcker, D. F. (1999). Corporate governance, chief executive officer compensation, and firm performance. Journal of Financial Economics, 51(3), 371-406.

Coşkun, M., \& Sayilir, Ö. (2012). Relationship between corporate governance and financial performance of Turkish companies. International Journal of Business and Social Science, 3(14), 59-64.

Editorial. (2003). Editorial Non-Executive Directors: key characteristics. Blackwell Publishing Ltd.

Elloumi, F., \& Gueyié, J. (2001). Financial distress and corporate governance: An empirical analysis. Corporate Governance: The International Journal of Business in Society, 1(1), 15-23.

Fama, E. F., \& Jensen, M. C. (1983). Separation of ownership and control separation of ownership and control. Journal of Law and Economics, 26(2), 301-325.

Fich, E. M., \& Slezak, S. L. (2008). Can corporate governance save distressed firms from bankruptcy? An empirical analysis. Review of Quantitative Finance and Accounting, 30(2), 225-251.

Hambrick, D. C., \& D'Aveni, R. A. (1992). Top team deterioration as part of the downward spiral of large corporate bankruptcies. Management Science, 38(10), 1445-1466.

Ho, S. S., \& Shun W, K. (2001). A study of the relationship between corporate governance structures and the extent of voluntary disclosure. Journal of International Accounting, Auditing and Taxation, 10(2), 139-156. 
Hong-xia, L., Zong-jun, W., \& Xiao-lan, D. (2008). Ownership, independent directors, agency costs and financial distress: Evidence from Chinese listed companies. Corporate Governance, 8(5), 622.

Jensen, M. C. (1993). The modern industrial revolution, exit, and the failure of internal control systems. The Journal of Finance, 48(3), 831880.

Jensen, M. C., \& Meckling, W. H. (1976). Theory of the firm: Managerial behavior, agency costs and ownership structure. Journal of Financial Economics, 3(4), 305-360.

Lakshan, A. M. I., \& Wijekoon, W. M. H. N. (2012). Corporate governance and corporate failure. Procedia Economics and Finance, 2(Af), 191-198.

Lamberto, A., \& Rath, S. (2010). The survival of initial public offerings in Australia. International Journal of Business and Finance Research, 4(1), 93-111.

Lima, B.F. \& Sanvicente, A.Z. (2013), Quality of corporate governance and cost of equity in Brazil, Journal of Applied Corporate Finance, 25(1), $72-80$.

Manzaneque, M., Priego, A. M., \& Merino, E. (2016). Corporate governance effect on financial distress likelihood: Evidence from Spain. Revista de Contabilidad, 19(1), 111-121.

Miglani, S., Ahmed, K., \& Henry, D. (2015). Voluntary corporate governance structure and financial distress: Evidence from Australia. Journal of Contemporary Accounting and Economics, 11(1), 18-30.

O'Connell, V., \& Cramer, N. (2010). The relationship between firm performance and board characteristics in Ireland. European Management Journal, 28(5), 387-399.

OECD. (n.d.). Corporate Governance and financial crisis. Retrieved from http://www.oecd.org

Sajid, G., Muhammad, S., Nasir, R., \& Farman, A. (2012). Agency cost, corporate governance and ownership structure: The case of Pakistan. International Journal of Business and Social Sciences, 3(9), 268-277.

Securities Commission Malaysia. (2007). Malaysian Code on Corporate Governance.

Shahwan, T. M. (2015). The effects of corporate governance on performance and financial distress. Journal of Financial Regulation and Compliance, 20(2), 169-181.

Shukeri, S. N., Shin, O. W., \& Shaari, M. S. (2012). Does board of director's characteristics affect firm performance? Evidence from Malaysian public listed companies. International Business Research, 5(9), 120-127. 
Simpson, W. G., \& Gleason, A. E. (1999). Board structure, ownership, and financial distress in banking firms. International Review of Economics and Finance, 8(3), 281-292.

Tao, N. B., \& Hutchinson, M. (2013). Corporate governance and risk management: The role of risk management and compensation committees. Journal of Contemporary Accounting and Economics, 9(1), 83-99.

Vafeas, N. (1999). Board meeting frequency and firm performance. Journal of Financial Economics, 53(1), 113-142.

Walsh, J., \& Seward, J. (1990). On the efficiency of internal and external corporate cntrol mechanisms. Academy of Management Review, 15(3), 421-458.

Witteloostuijn, D. R. \& A. Van. (2009). Board Independence, CEO Duality and Firm Performance A Quantile Regression Analysis for Indonesia, Malaysia, South Korea and Thailand. Demography (Vol. 13).

Wruck, K.H. (1990), Financial distress, reorganization, and organizational efficiency, Journal of Financial Economics, 27, 419-44.

Yusoff, W., \& Alhaji, I. (2012). Corporate governance and firm performance of listed companies in Malaysia. Trends and Development in Management Studies, 1(1), 43-65. 